\title{
CONTROL OF FUEL CELL/BATTERY SOURCE FOR ELECTRIC VEHICLES
}

\author{
Ayse Kocalmis Bilhan ${ }^{1}$. Abuzer Çalışkan ${ }^{2}$ \\ ${ }^{1}$ Nevsehir H.B.V. University, Electrical Electronic Eng. Dept., Nevsehir, Turkey \\ ${ }^{2}$ Firat University, Electrical Electronic Eng. Dept., Elazı̆̆/Turkey, acaliskan@firat.edu.tr \\ Corresponding author; akbilhan@nevsehir.edu.tr
}

\begin{abstract}
Fuel cells are considering as primary power source for portable applications, electrical vehicles and residential applications in the future. However, since the voltage value obtained from a single fuel cell is too low, the output voltage values of the fuel cells must be increased. Therefore, $D C / D C$ and DC/AC converters should be used to obtain a balanced output voltage and to make FCs available for all applications. This paper discusses the principle and electrical characteristics of the fuel cell, DC/DC boost converter and DC/AC inverter.
\end{abstract}

\section{Introduction}

In last years, alternative energy sources such as solar, wind, geothermal and etc. have become very popular. They do not cause pollution as well as being clean, sustainable. However, it has been observed that alternative energy sources vary depending on geographical location and weather conditions. Therefore, researchers are focused on portable, efficient alternative energy sources in small size and Fuel Cells (FCs) are one of them. FCs are electrochemical devices that convert the chemical energy into electricity. They are modular, safe and quite. Also low emission, good transient response and high scalability are another advantage of this technology. FCs reduce carbon dioxide emissions compared to traditional energy sources are used. Therefore, FCs can be used in many applications such as residential, portable, vehicle, space and etc. By this reasons, automakers and customers started to give more attention to the electric, hybrid, plug-in and fuel cell vehicle [1].

Compared to the conventional vehicles, electrical vehicle (EV), hybrid electric vehicle (HEV), plug-in vehicle or Fuel Cell vehicles (FCs) use more electrical components and circuits [2,3]. These components are used for power electronics, electrical machines or embedded powertrain controllers. A hybrid electric powertrain drive utilizes two or more energy sources for propulsion. Plug-in vehicles are charged overnight from the power grid where energy can be generated from renewable sources such as wind and solar energy. FCs use hydrogen as fuel to produce electricity. FCs basically are called as an electrochemical device which convert chemical energy into electrical energy [3]. It provides zero emission, high reliability and quietness in the operation process. Water and heat are the only co-product. Especially, FCs has been considered as a primary energy sources for the next generation EVs. However, FCs have a couple of disadvantages such as they cannot store energy or their response is slow. Therefore, Hybrid FCs vehicle uses a combination of FCs, Batteries and Supercapacitors (SCs) to power electrical drive system. However, one of the problems that still limits the use of FCs is the high cost. All new 
researches are have been focused on to develop low-cost systems and reliable hybrid electric powertrain [4].

The main problem of designing automotive fuel cell power systems is to convert the electrical output from the FCs into a usable power for various system sizes. Furthermore, another aim is to utilize the full potential of fuel cell technology using the right methods for converting fuel cell output into a useful electrical or mechanical energy. Also a suitable DC/AC converter leads DC power from FCs, batteries or SCs to drive the powertrain $[5,6]$.

This paper is mainly focused on power electronics circuits for FCs vehicle applications and it is divided into 5 sections. In section 2 and 3, FCs structure and Power converter circuits are described. The simulation results are given in fourth section and conclusions are given in final section.

\section{FCs Structure}

A fuel cell generates electricity in a single step without involving any moving parts [7]. In principle, FCs are similar to batteries as they convert chemical energy directly to electricity and water is the only by-product in this process. However, the fuel cells do not need to be charged unlike battery. As long as fuel cells have fuel and oxygen, there is a constant flow of power. Hydrogen is the main choice of fuel for most applications due to its high energy density and ability to be produced from wide range of other energy sources such as from solar, wind, hydro or geothermal energy. A block scheme has been shown in Fig. 1 (a).

In Figure 1 (b), a basic structure of FCs has been shown. The fuel cell consists of an electrolyte and two electrodes (the anode and the cathode), which surrounds the electrolyte. The anode electrode is named as fuel electrode and the cathode electrode is named as oxygen electrode. The hydrogen atom is separated into a proton and an electron that will travel in different ways in the cathode with the aid of the catalyst. While the proton passes through the electrolyte, electrons return to the cathode and combine with hydrogen and oxygen to form an electrical current before forming the water molecule. [6-8].

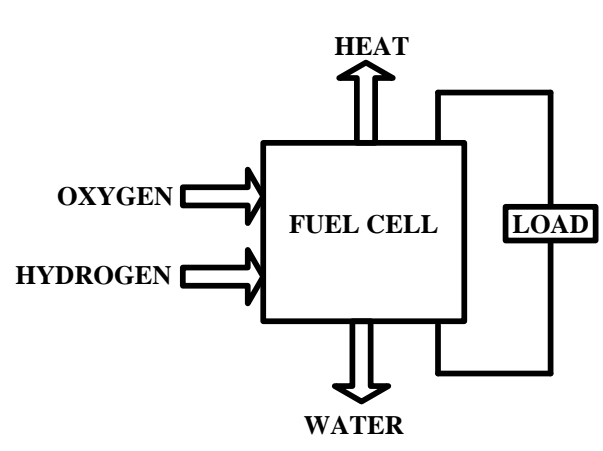

(a)

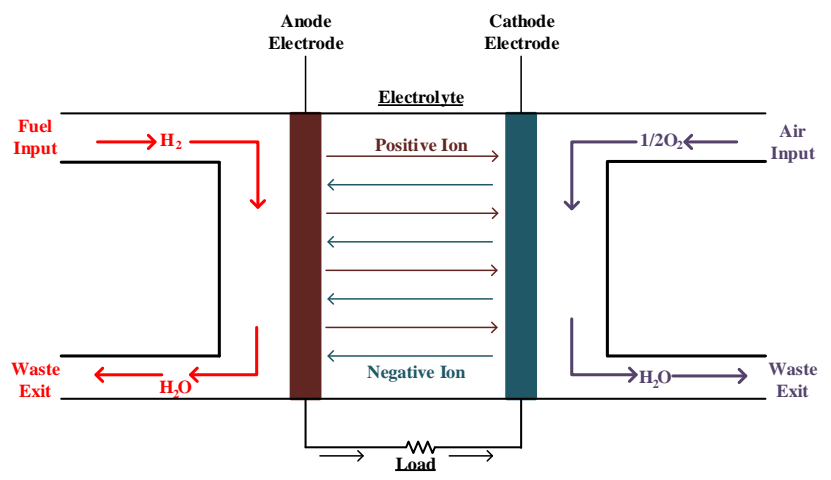

(b)

Figure 1. (a) Block Diagram, (b) A basic structure of FCs.

The overall reaction of FCs can be summarized as;
Anode Reaction:
$\mathrm{H}_{2} \rightarrow 2 \mathrm{H}++2 \mathrm{e}^{-}$
Cathode Reaction:
$1 / 2 \mathrm{O}_{2}+2 \mathrm{H}++2 \mathrm{e}^{-} \rightarrow \mathrm{H}_{2} \mathrm{O}+$ Heat
Overall Reaction:
$\mathrm{H}_{2}+1 / 2 \mathrm{O}_{2} \rightarrow \mathrm{H}_{2} \mathrm{O}+$ Heat 
Fuel cells can be grouped by the type of electrolyte such as alkaline FCs (AFCs), polymer electrolyte membrane or proton exchange membrane FCs (PEMFC), phosphoric acid FCs (PAFC), molten carbonate FCs (MCFC) and solid oxide FCs (SOFC).

In all of the FCs types, Proton Exchange Membrane FCs (PEMFCs) are getting attention because of their simplicity, quick start up, high power density and long life as well as low corrosion. While the polymer membrane layer inside the fuel cells does not carry the gases (an insulator of electrons), they excellent conductor of protons (and thus the proton exchange membrane). Due to PEMFCs have the ability to deliver such high power densities at very low temperature, they can be made smaller which reduces overall weight and cost to produce [9]. They have great efficiency compared to heat engine and propulsion of electrical vehicles is promising [10].

In Fig. 2, a FC equivalent circuits has been shown. $\mathrm{R}_{\text {ohmcell }}$ (ohmic resistance) is a function of FC temperature. $\mathrm{R}_{\text {ccell }}$ and $\mathrm{R}_{\text {actcell }}$ are resistances of concentration ad activation voltage components. The output voltage of a single cell can be calculated by using Eq. (1) [11-13].

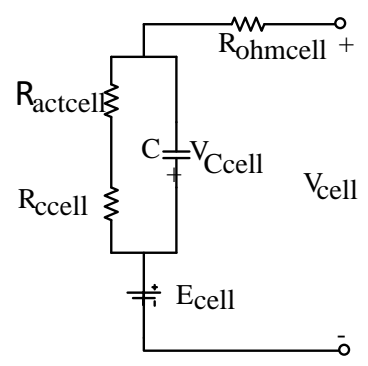

Figure 2. A FC equivalent electric circuit

$$
\mathrm{V}_{\text {cell }}=\mathrm{E}_{\text {cell- }}-\mathrm{V}_{\text {actcell}}{ }^{-} \mathrm{V}_{\text {ohmcell }}-\mathrm{V}_{\text {ccell }}
$$

where; $\mathrm{E}_{\text {cell }}$ is the single cell electromotive force $(\mathrm{V}), \mathrm{V}_{\text {ccell }}$ (concentration) is voltage drops in FCs, $\mathrm{V}_{\text {acteell }}$ (activation) is voltage drop due to the activation of the anode and cathode, $\mathrm{V}_{\text {ohmcell }}$ (ohmic) is voltage drops in FCs, and $\mathrm{V}_{\text {cell }}$ is a single output voltage of FCs. Also $\mathrm{E}_{\text {cell }}$ can be calculated by using Nerst equation as shown in Eq. 2.

$$
\mathrm{E}_{\mathrm{cell}}=\mathrm{E}_{0}-0.85 \times 10^{-3}\left(\mathrm{~T}-\mathrm{T}_{\mathrm{c}}\right)+\frac{\mathrm{RT}}{2 . \mathrm{F}} \ln \left(\sqrt{\mathrm{P}_{\mathrm{O}_{2}}} \mathrm{xP}_{\mathrm{H}_{2}}\right)
$$

where; $\mathrm{T}$ is a cell temperature in Kelvin, $\mathrm{E}_{0}$ is the reversible nearest potential, $\mathrm{T}_{\mathrm{c}}$ is the temperature correction offset, $\mathrm{P}_{\mathrm{O}_{2}}$ is the oxygen pressure, $\mathrm{P}_{\mathrm{H}_{2}}$ is the hydrogen pressure, $\mathrm{R}$ is the ideal gas constant, and $\mathrm{F}$ is the Faraday constant [14]. $\left(\mathrm{E}_{0}=1.229 \mathrm{~V}, \mathrm{~T}_{\mathrm{c}}=298.15 \mathrm{~K}\right.$, and $\left.\mathrm{R}=8.31 \mathrm{~J} / \mathrm{mol}\right)$

The voltage produced from one cell is between $0-1 \mathrm{~V}$. The voltage ratio depends on FC operating conditions and the size of load connected to the FC. But generally, typical value of the FC voltage is approximately $0.7 \mathrm{~V}$. To get higher voltage, multiple cells are stacked in series and parallel. The fuel cell stacks are constructed by stacking several individual cells such as connecting several voltage sources in series. The number of series and parallel stacks can be calculated by using Eq. 3 . However, connecting many FCs in series can occur some problems such as complex plumbing to evenly 
distribute fuel. For low power applications the number of cells that needs to be connected in series is small, but as power increases the number of cells that are required in the stack increases rapidly and it is called as a FC Power Plant (FCPP). In Fig. 3, FCs stack structure has been shown.

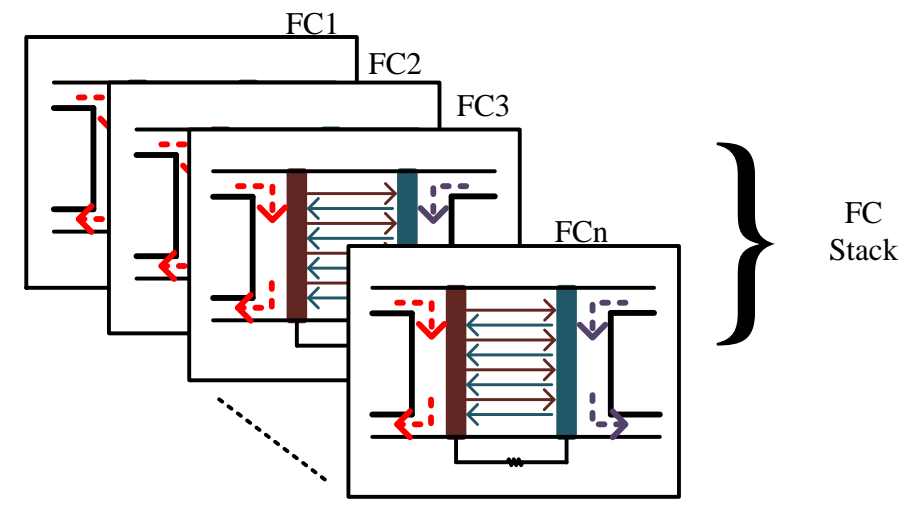

(a)

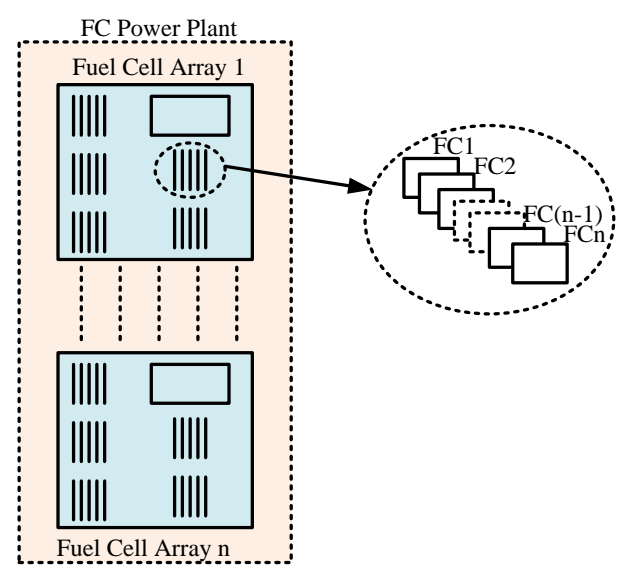

(b)

Figure 3. FCs stack structure

$$
\left.\begin{array}{c}
\mathrm{N}_{\mathrm{S}}=\frac{\mathrm{V}_{\mathrm{FC}}}{\mathrm{V}_{\text {stack }}} \\
\mathrm{N}_{\mathrm{P}}=\frac{\mathrm{P}_{\mathrm{FC}}}{\mathrm{N}_{\mathrm{S}} \cdot \mathrm{P}_{\text {stack }}}
\end{array}\right\}
$$

where, $N_{S}$ is the number of series stack, $N_{P}$ is the number of parallel stack, $V_{F C}$ is output voltage of the FCs, $\mathrm{V}_{\text {stack }}$ is the operation point of the FC stack, $\mathrm{P}_{\mathrm{FC}}$ is output power of the FCs and $\mathrm{P}_{\text {stack }}$ is the operation power of the FC stack.

\section{Power Electronics Circuit FCs Vehicles}

The output of the electric machine provides a mechanical output for driving the vehicle's wheels. As a mentioned in the previous section, a low DC voltage is produced as an output of the FCs. This DC voltage is applied to an electric machine with a suitable power electronic DC/DC converter and DC/AC converter. Also another controller is used as a connection between the fuel cell system and the vehicle load. While the controller is on, the feedback from the vehicle is received to the controller and suitable signal is send to the FCs. A FC based traction motor drive application diagram has been shown in Fig. 4. 


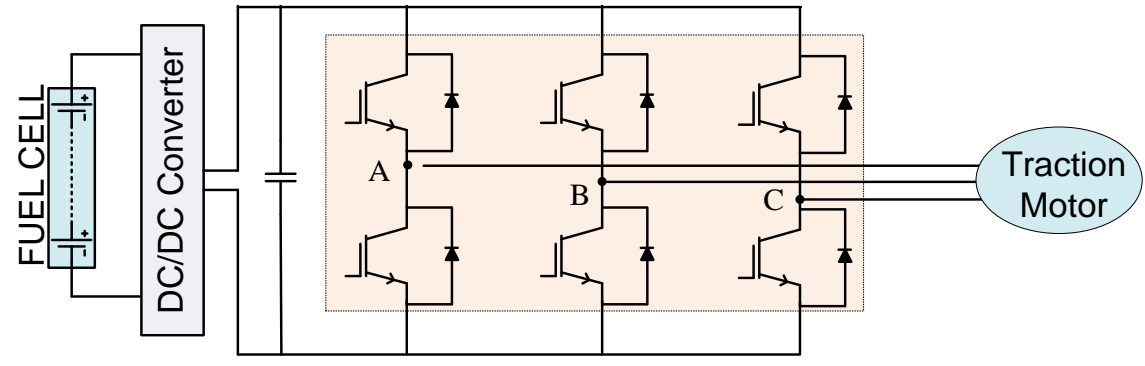

Figure 4. A FC based traction motor drive

\subsection{DC/DC Converter Design}

The DC/DC boost converter scheme has been shown in Fig. 5. The electronic components are assumed to be ideal. So, losses in the inductive and capacitive elements are neglected. Also, DC / DC boost converter is used because of the input current is continuous and it has a simple structure. For time interval d.T, the $\mathrm{S}$ (switch) is switched on and D (diode) is off. For time interval (1-d).T, the S (switch) is switched off and D (diode) is on. $\mathrm{T}$ and $\mathrm{f}$ can be defined as time period and switching frequency, respectively. Also, the duty cycle (d) of DC/DC boost converter can be calculated as in Eq. (4).

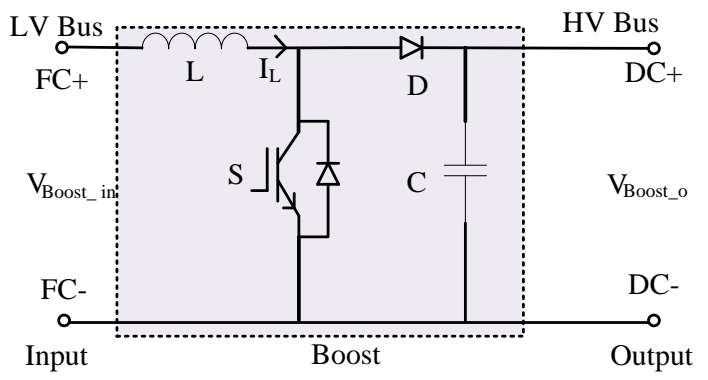

Figure 5. DC/DC Boost converter model

In the boost converter, High Voltage (HV) bus has higher voltage value than Low Voltage (LV) bus. When fuel cell working, DC/DC converter is not only increase the voltage amplitude it also produces balanced output voltage. The duty cycle (d) of DC/DC boost converter can be calculated as in Eq. (4).

$$
\mathrm{V}_{\mathrm{i}}=\frac{\mathrm{V}_{\mathrm{o}}}{\mathrm{d}-1}
$$

\subsection{DC/AC Inverter Design}

$\mathrm{DC}$ power is converted into $\mathrm{AC}$ power by using DC/AC inverters. A simple 3-phase AC inverter bridge topology which has 2 switches in each phase has been shown in Fig. 6 (a). Basically, in order to obtain a square wave output voltage, each switch in the same phase must remain open for half the period and remain closed for the next half period. Although the most basic switching method is a six-step switching method, many different pulse width modulation techniques have been developed over time [15-16]. In this paper, Sinusoidal Pulse Width Modulation (PWM) technique has been used. The switching signal is calculated by comparing a sinusoidal reference signal $\left(V_{R}\right)$ with a triangular carrier wave $\left(V_{C}\right)$ such 
as Fig 6. (b). The output voltage amplitude of inverter is calculated by using the Modulation $\operatorname{Index}\left(\mathrm{m}_{\mathrm{i}}\right)$ which is calculated by using $m=V_{R} / V_{C}$. The desired magnitude and frequency of the output voltage is obtained by using inverter. Basically, recently many researchers focus on the cost and the size of the DC/AC inverter drive systems.

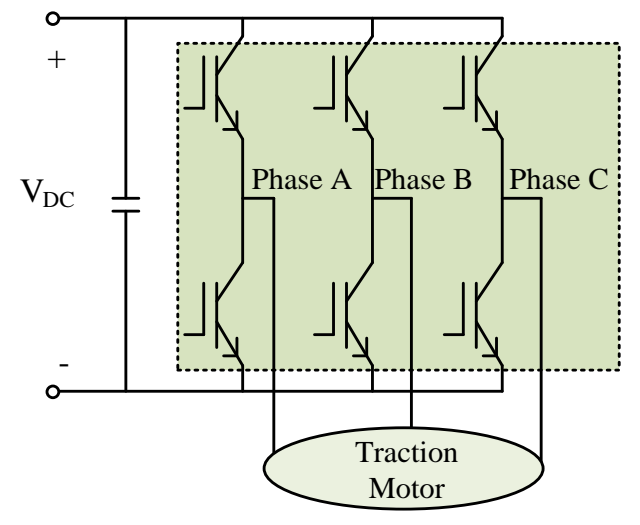

(a)

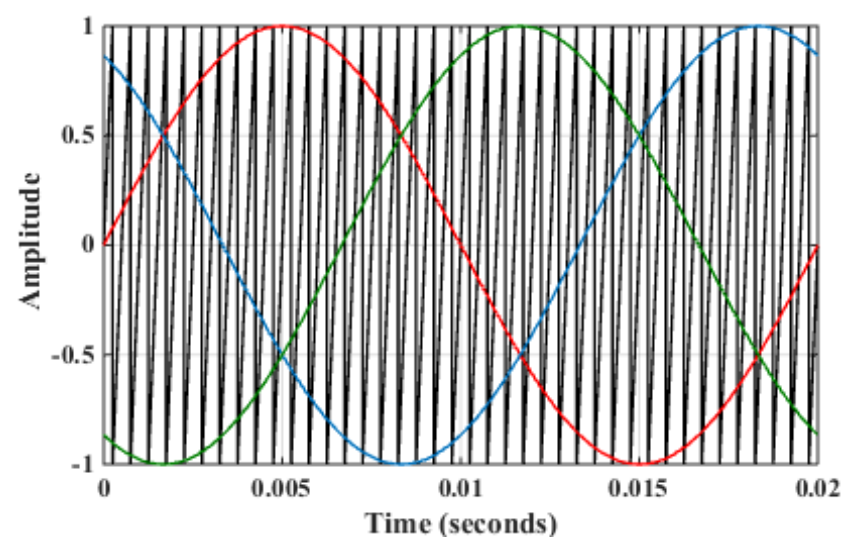

(b)

Figure 6. (a) DC/AC Inverter model, (b) Modulation Signals

\section{System Model}

Basically, a fuel cell is supplied with hydrogen fuel and air to produce a low DC voltage. This low voltage produced is processed with the appropriate DC / DC converter and DC / AC inverter to reach the desired voltage value for use in an electric machine. A block diagram of typical hybrid fuel cell based drive system is shown in Fig. 7.

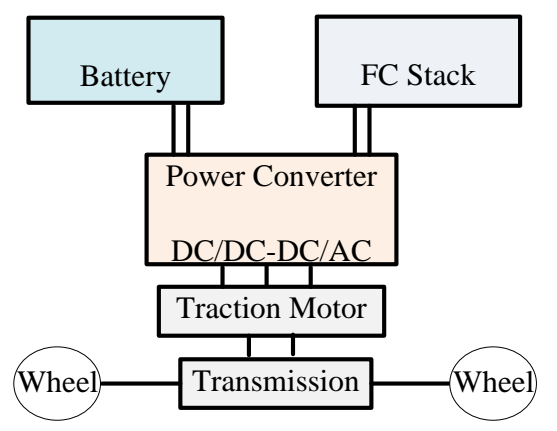

Figure 7. Typical hybrid fuel cell based vehicle drive system.

The performance of the proposed system is simulated by using Matlab/Simulink package program. In the simulation RL passive load is used. The values of $\mathrm{R}$ and $\mathrm{L}$ are $100 \Omega, 0.1 \mathrm{H}$, respectively. The Matlab/Simulink model of the system has been shown in Fig. 8. 


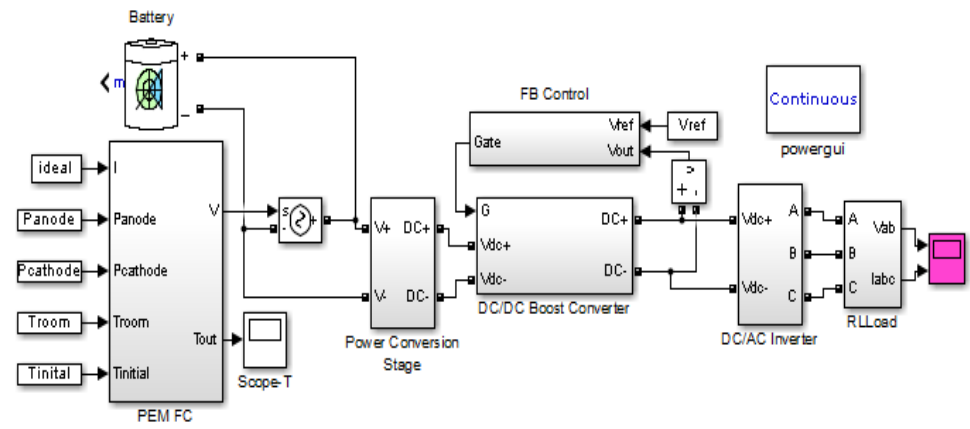

Figure 8. Matlab/Simulink model of system.

The output voltage of FC has been shown in Fig. 9. The duty cycle (d) of the converter is chosen as a $2 / 3$, so the output voltage of the converter is $114,3 \mathrm{~V}$.

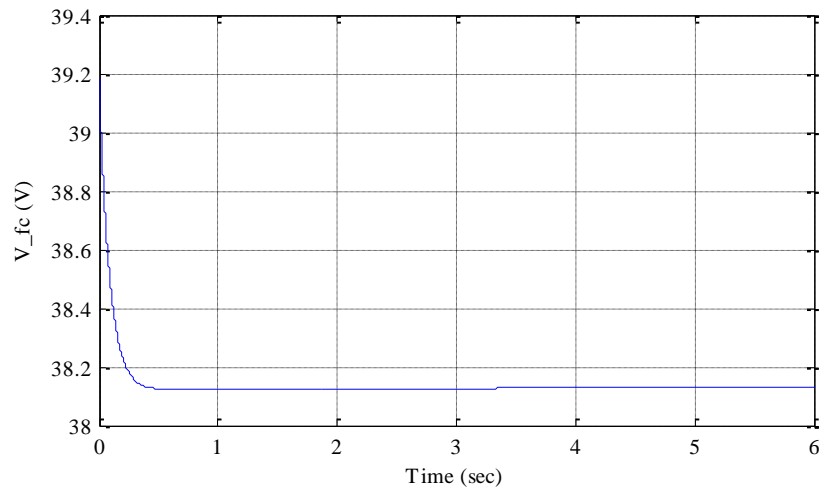

Figure. 9 The output voltage of FC

The single phase output current $\left(\mathrm{I}_{\mathrm{b}}\right)$, three phase output currents $\left(\mathrm{I}_{\mathrm{a}}, \mathrm{I}_{\mathrm{b}}, \mathrm{I}_{\mathrm{c}}\right), \mathrm{V}_{\mathrm{ao}}(\mathrm{V})$ and $\mathrm{V}_{\mathrm{ab}}(\mathrm{V})$ voltage waveforms have been shown in Fig. 10 and Fig. 11 respectively.

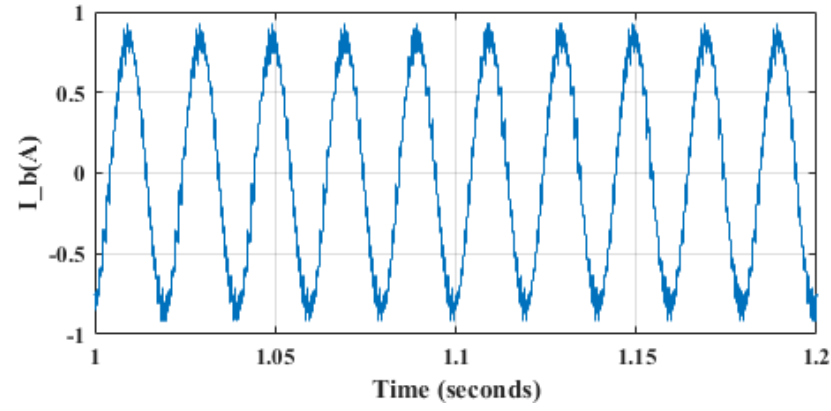

(a)

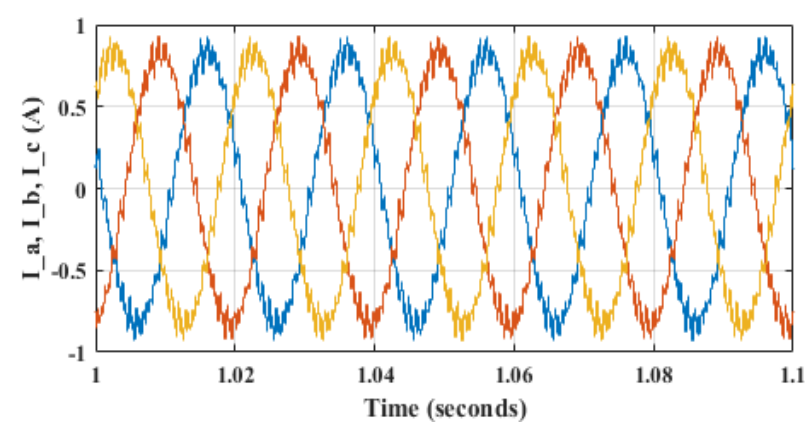

(b)

Fig. 10 a)- The single phase output current waveform $\left.\left(I_{b} A\right), b\right)$ - Three phase output current waveform $\left(\mathbf{I}_{\mathbf{a}}, \mathbf{I}_{\mathbf{b}}, \mathbf{I}_{\mathbf{c}} \mathbf{A}\right)$ 


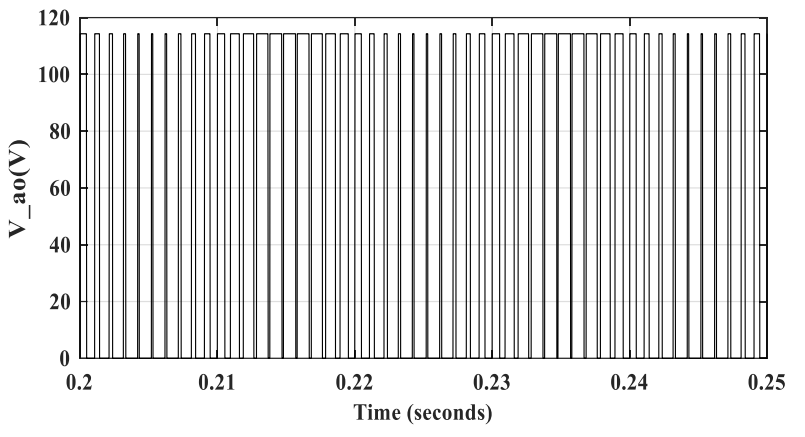

(a)

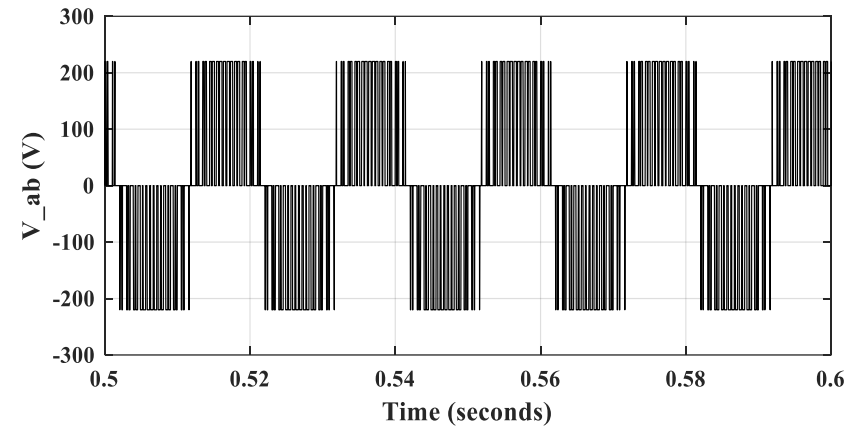

(b)

Fig. 11 (a)- $V_{a o}(V)$ output voltage waveform, (b)- $V_{a b}(V)$ three phase output voltage waveform

\section{Conclusions}

Environmental concerns and limited energy sources give opportunity to research on alternative energy sources and technologies. Especially, FCs vehicles have been considered for the next generation automotive industry and the consumer. When designing electric vehicles, the development of large electric driven trains will increase fuel efficiency, resulting in lower emissions and possibly better vehicle performance (acceleration and braking). But at the same time, its complex technology forces the researches to solve the problems such as cost, size and etc. In this paper, modular FCs, DC/DC boost converter and three-phase inverter structure has been presented and modelled. Recent studies have showed that modelling and simulation play important roles in the success of FCs, hybrid or Electric Vehicle design and development.

\section{References}

[1] D. W. Gao, C. Mi, A. Emadi, "Modeling and Simulation of Electric and Hybrid Vehicles", IEEE, Vol. 95, No.4, pp.729-745, 2007.

[2] J. Sheng, D. J. Nelson, "Energy Management Power Converters in Hybrid Electric and Fuel Cell Vehicles”, IEEE, Vol. 95, No.4, pp.766-777, 2007.

[3] Z. Q. Zhu, D. Howe, "Electrical Machines and Drives for Electric, Hybrid, and Fuel Cell Vehicles", IEEE, Vol. 95, No.4, pp.746-765, 2007.

[4] A. Emadi, S.S. Williamson, "Fuel Cell Vehicles: Opportunities and Challenges", Power Engineering Society General Meeting, Vol.2, pp. 1640-1645, 2004.

[5] L. M. Tolbert, S. Z. Peng, t. Cunnyngham, J.N. Chiasson, "Charge Balance Control Schemes for Cascade Multilevel Converter in Hybrid Electric Vehicles", IEEE Trans. on Industrial Applications, Vol. 49, No. 5, pp. 1058-1064, 2002.

[6] K. Jin, X. Ruan, M. Yang, M. Xu, “A Hybrid Fuel Cell Power System”, IEEE Trans. on Industrial Electronics, Vol. 56, No.4, pp: 1212-1222, 2009. 
[7] F. Barbir, "PEM Fuel Cells: Theory and Practice", Elsevier, Academic Press Sustainable World Series, 2005.

[8] T. P., Kumar, N., Subrahmanyam, M., Syduu, "Control Strategies of a Fuzzy Controlled Solid Oxide Fuel Cell/Battery Distributed Generation System for Power Quality Enhancement”, International Conf. on Circuit, Power and Comuputing Tech. (ICCPCT), pp. 64-69, 2014.

[9] A. Kazim, "Exergy Analysis of PEM Fuel Cell at Variable Operating Conditions", Energy Conversion and Management, Vol. 45, pp. 1949-1961, 2004.

[10] S. Chaudhary, Y.K. Chauhan, "Studies and Performance Investigations on Fuel Cells", IEEE International Conference on Advances in Engineering \& Technology Research ICAETR, 2014.

[11] C. Wang, M. H. Nehrir, H. Gao, "Control of PEM Fuel Cell Distributed Generation Sytems", IEEE Trans. on Energy Conversion, Vol. 21, No.2, pp. 586-595, 2006.

[12] M. H. Nehrir, C. Wang, "Modeling and Control of Fuel Cells", Wiley, IEEE Pres., 2009.

[13] C. Wang, M. H., Nehrir, S.R. Shaw, "Dynamic Models and Model Validation for PEM Fuel Cells Using Electrical Circuits", IEEE Trans. on Energy Conversion, Vol. 20, No. 2, pp. 442-451, 2005.

[14] K. W. E. Cheng, D. Sutanto, Y. L. Ho, and K. K. Law, "Exploring the power conditioning system for fuel cell,” in Proc. IEEE PESC, pp. 2197-2202, 2001.

[15] F. Gao, B. Blunier, M.G. Simoes, A. Miraoui, "PEM Fuel Cell Stack Modeling for Real-Time Emulation in Hardware-in-the-Loop Applications", IEEE Trans. on Energy Conversion, Vol. 26, No. 1, pp. 184-194, 2011.

[16] I. Colak, E. Kabalci, R. Bayindir, "Review of multilevel voltage source inverter topologies and control schemes”, Energy Conversion and Management, 52(2), pp. 1114-1128, 2011. 